\title{
Pneumatologia w isagodze Juniliusza Afrykańczyka
}

\section{Pneumatology in the Isagoge of Junilius Africanus}

\section{BOGDAN CZYŻEWSKI}

Uniwersytet im. Adama Mickiewicza w Poznaniu, Poznań

czybo@amu.edu.pl, ORCID: 0000-0002-6040-5523

Streszczenie: Niewielkie dzieło starożytnego autora Juniliusza Afrykańczyka (VI w.) Instituta regularia divinae legis jest wprowadzeniem (isagogą) do poznawania Pisma Świętego. Porządkuje nie tylko kanon ksiąg Starego i Nowego Testamentu, ale zawiera również zwięzłą interpretację niektórych tekstów biblijnych. Obok wielu kwestii doktrynalnych Juniliusz zajmuje się w swoim biblijnym podręczniku także pneumatologią. Odczytuje ją w podwójnej perspektywie. Ducha Świętego określa jako łaskę, którą jest On sam, ponieważ udziela się jako dar człowiekowi. Drugi temat to ukazanie jedności Ducha Świętego z Ojcem i Synem, i odrębności Osób Boskich w perspektywie trynitarnej.

Słowa kluczowe: Juniliusz Afrykańczyk; Duch Święty; isagoga; Instituta; Augustyn

Abstract: The work of the ancient author Junilius Africanus (6th century), Instituta regularia divinae legis, is an interesting introduction (isagoge) to the study of the Holy Scriptures. It not only organizes the canon of the Old and New Testaments, but also contains concise interpretations of some of the biblical texts. Among many other doctrinal questions, Junilius deals in his biblical textbook with pneumatology. It presents pneumatology through a double perspective. First, the Holy Spirit is defined as the grece, that $\mathrm{He}$ is himself, because He gives himself as a gift to man. The second theme shows both the unity of the Holy Spirit with the Father and the Son and also the separateness of the Divine Persons, in the Trinitarian perspective.

Keywords: Junilius Africanus; Holy Spirit; isagoge; Instituta; Augustine

Juniliusz Afrykańczyk nie należy do czołowych i znanych postaci Kościoła pierwszych wieków. Napisał jedno tylko dzieło, którego łaciński tytuł brzmi Instituta regularia divinae legis (= Instituta) (Zasady prawa Bożego) ${ }^{1}$. Określa się je jako wprowadzenie do poznawania Pisma Świętego, dlatego też w obszernej monografii, w całości poświęconej temu dziełu, nazwane zostało isagogą ${ }^{2}$. Mamy tutaj bowiem do czynienia $\mathrm{z}$ wiadomościami propedeutycznymi potrzebnymi do studiowania i poznawania Pisma Świętego. Isagoga zaś to nic innego, jak nauka wstępna, przygotowawcza do

\footnotetext{
1 Posługuję się wydaniem krytycznym Instituta regularia divinae legis Juniliusza, które opracował H. Kihn (Theodor von Mopsuestia und Junilius Africanus als Exegeten, 465-528.

2 Por. Czyżewski, Księgi Pisma Świętego, 16.
} 
obszernej nauki, zwłaszcza do studiów biblijnych ${ }^{3}$. O znaczeniu tego dzieła świadczy fakt, że we wczesnym średniowieczu znane ono było w klasztorach. Polecano też jego lekturę tym wszystkim, którzy pragnęli rozpocząć studiowanie Pisma Świętego ${ }^{4}$.

Nie wiemy dokładnie, skąd pochodził Juniliusz Afrykańczyk ${ }^{5}$. Był osobą świecką zainteresowaną Pismem Świętym i literaturą kościelną. Za czasów cesarza Justyniana (527-565) pełnił w Konstantynopolu przez kilka lat odpowiedzialną funkcję quaestor sacri palatii, co dawało mu możliwość zajmowania się sprawami natury prawniczej. Owocem jego zainteresowań Biblią było wspomniane niewielkie dzieło, napisane w języku łacińskim i posiadające ciekawą formę dialogu prowadzonego między uczniem i nauczycielem ${ }^{6}$. Znaczenie Instituta wynika z tego, że Juniliusz podejmuje w nim istotne kwestie dotyczące aspektu formalnego i doktrynalnego Pisma Świętego. Co więcej, autor Instituta należy do postaci kontrowersyjnych. Polemiki wokół jego osoby pojawiły się jednak dopiero w czasach nowożytnych i dotyczyły przede wszystkim jego rzekomych związków z Teodorem z Mopsuestii i ze środowiskiem nestoriańskim ${ }^{7}$. Opinię taką zaczął formułować od końca XIX wieku Heinrich Kihn, który krytycznie wydał dzieło Juniliusza, a także obszerne opracowanie, będące porównaniem Instituta z niektórymi wypowiedziami Teodora z Mopsuestii ${ }^{8}$. Niemiecki uczony podnosi zasadniczo dwie kwestie związane z Instituta naszego autora. Uważa on, że Juniliusz powtarza myśl egzegetyczną i teologiczną biskupa Mopsuestii, a tym samym idee nestoriańskie szkoły w Nisibis. Ponadto sądzi, że autorem Instituta nie jest Juniliusz, tylko Paweł Pers, nasz Afrykańczyk natomiast jedynie przetłumaczył z greki na łacinę jego dzieło'.

Opracowania późniejsze dotyczące Juniliusza były raczej fragmentaryczne ${ }^{10}$. Poza dwoma artykułami, w których brakuje pogłębionego studium nad kanonem biblijnym Juniliusza i analizy aspektów dogmatycznych ${ }^{11}$, znaleźć można jedynie krótkie hasła encyklopedyczne, w których powtarza się opinie H. Kihna o wpływie

3 Termin isagoga pochodzi od greckiego eisagoge i oznacza wprowadzenie (por. Kopaliński, Stownik wyrazów obcych, 196; Szymczak, Słownik języka polskiego, 808).

4 Przykładem tego jest biblioteka Kasjodora w Vivarium, która zawierała kopie Instituta Juniliusza, sam zaś Kasjodor polecał je czytać mnichom (por. Cassiodorus, Institutiones I, 10 [PL 70,1122]).

5 Bardziej szczegółowe informacje na temat samego Juniliusza i jego dzieła zob. Czyżewski, Księgi Pisma Świętego, 6-18, idem, „Wprowadzenie”, 7-20.

6 Por. Czyżewski, Księgi Pisma Świętego, 16.

7 Z autorów zagranicznych najwięcej miejsca poświecili Juniliuszowi i jego dziełu H. Kihn (Theodor von Mopsuestia und Junilius Africanus als Exegeten) i L. Pirot (Loeuvre exégétique de Théodore de Mopsueste).

8 Opracowanie H. Kihna zawiera nie tylko analizę dzieła Juniliusza, ale także jego krytyczne wydanie.

9 Por. Kihn, Theodor von Mopsuestia und Junilius Africanus.

10 Przykładem może być krótka wypowiedź A. Guillaumont („Justinien et l’Église de Perse”, 47-48), który powtarza opinię H. Kihna i mówi, że Instituta należały do Pawła Persa, przetłumaczone zostały przez Juniliusza i stanowią świadectwo nauczania w szkole w Nisibis, a tym samym zawierają poglądy Teodora z Mopsuestii.

11 Por. Mannino, „Gli Instituta di Giunilio”, 405-419; Stein, „Deux questeurs de Justinien”, 365-390. 
Teodora z Mopsuestii i Pawła Persa na dzieło Juniliusza ${ }^{12}$. Dopiero na początku XXI wieku powstało kilka opracowań, których autor sugeruje całkowicie inne spojrzenie i odczytanie dzieła naszego Afrykańczyka ${ }^{13}$.

W isagodze Juniliusza pojawia się ciekawy wątek związany z nauką na temat Ducha Świętego. Należy na samym początku zaznaczyć, iż nie jest ona z całą pewnością wyczerpująca, ponieważ nasz autor nie zamierzał wyłożyć całościowej doktryny odnoszącej się do teologii Ducha Świętego, co raczej podać najważniejsze jej aspekty. Można zatem powiedzieć, iż są to wypowiedzi związane z wyjaśnieniem niektórych tekstów biblijnych. Celem zatem niniejszego artykułu jest przedstawienie pneumatologii, która wyłania się z działa Juniliusza.

\section{Duch Święty darem i łaską}

W rozdziałach dotyczących nauki o Bogu Juniliusz omawia sposoby, przy pomocy których określana jest w Piśmie Świętym trzecia Osoba Trójcy Świętej. Żeby zrozumieć jego myśl, musimy najpierw wyjaśnić dosyć często używane przez niego dwa łacińskie słowa, a mianowicie: principaliter i consequenter. Wyrażenia te można uznać za terminy techniczne, ponieważ na pytanie ucznia, najczęściej sformułowane jako Quot modis...? udzielana jest odpowiedź ze strony nauczyciela: Duobus: principaliter et consequenter ${ }^{14}$. Po tej krótkiej odpowiedzi następuje rozwinięcie tematu i wyjaśnienie, co Juniliusz rozumie przez wspomniane wyrażenia. Należy również dodać, że wymienione techniczne terminy pojawiają się między innymi w tekście Instituta, kiedy jest mowa o sposobach określania Trójcy Świętej, jak i poszczególnych Osób Boskich. Wspomniane słowa nie należą do łatwych do przetłumaczenia, są jednak niezwykle ważne, o czym się przekonamy analizując fragmenty tekstu Juniliusza ${ }^{15}$.

12 Por. np. Peterson, „Giunilio Africano”, 762-763; Buchwald - Hohlweg - Prinz, „Junilius Africanus”, 496; Gessel, „Junilius (Junillus) Africanus”, 1101; Bruns, „Junilius Africanus”, 365.

13 Polemikę z H. Kihnem i L. Pirotem oraz dokładne studium dzieła Juniliusza, jego zależności i związki z innymi autorami starożytnymi podejmuje Czyżewski w swoim opracowaniu Księgi Pisma Świętego. Wykazuje on, iż dzieło Juniliusza jest oryginalne, w pełni ortodoksyjne, jego autor pozostawał zaś pod wypływem myśli pisarzy zachodnich, zwłaszcza św. Augustyna. Inne opracowania na temat Juniliusza: Czyżewski, „Elementy angelologii”, 409-420; idem, „Wykorzystanie teorii egzegezy”, 147-159; idem, „Isagoga Juniliusza Afrykańczyka”, 11-19.

14 Por. Junilius Africanus, Instituta I, 13; I, 14; I, 15; I, 16; I, 17.

15 Termin principaliter pochodzi od principalis i dosłownie oznacza „szczególnie, wybornie, znakomicie” (por. Plezia, Słownik łacińsko-polski, 291). Zasugerowany przez nas przekład principaliter jako „bezpośrednio” znajduje swoje uzasadnienie w wypowiedziach Juniliusza, który mówi, że Bożą istotę w sensie principaliter określają słowa odnoszące się wyłącznie do Boga i bezpośrednio o Nim orzekają. Chodzi tutaj o terminy: Deus, Dominus, Dominus Deus, Adonai, Sabaoth, Heli, Heloi, Est (por. Junilius Africanus, Instituta I, 13). Principaliter u Juniliusza to zatem mówienie o istocie i naturze Boga w sensie bezpośrednim. Z kolei consequenter pochodzi od consequens i dosłownie oznacza „odpowiednio do 
Zaproponowaliśmy przekład principaliter jako „bezpośrednio”, co wydaje się być całkowicie uzasadnione, ponieważ nasz autor odnosi ten termin do tych miejsc w Biblii, w których mówi ona bezpośrednio o Ojcu, Synu i Duchu Świętym oraz o Bożej istocie (divina essentia). Oto przykład, w którym ten termin się pojawia. Uczeń zadaje pytanie: „Uczeń: Iloma sposobami określa Pismo Osoby lub hipostazy Boskie? Nauczyciel: Podobnie dwoma: bezpośrednio (principaliter) i pośrednio (consequenter). Bezpośrednio (principaliter), kiedy mówimy Ojciec, Syn, Duch Święty"16. W znaczeniu principaliter są to zatem orzeczenia w sensie absolutnym, gdyż odnoszą się wyłącznie i bezpośrednio do Ojca, Syna i Ducha Świętego. Drugi techniczny termin, consequenter, przełożyliśmy jako „pośrednio”. Wskazuje on także na Boga w Trójcy Świętej Jedynego, ale występuje wówczas, kiedy mowa jest o Bóstwie, działaniu lub też porównywaniu Osób Boskich poprzez analogię do stworzeń ${ }^{17}$. Wyżej zacytowaną odpowiedź nauczyciel kontynuuje w następujący sposób: „Pośrednio (consequenter) zaś przez te [słowa], którymi oznaczana jest istota, albo działanie, albo analogia do stworzeń" ${ }^{18}$. Chodzi zatem o wskazanie na przymioty, które dotyczą poszczególnych Osób Boskich bądź Trójcy Świętej rozumianej jako jedność Osób ${ }^{19}$.

Po tym wyjaśnieniu przejdźmy do konkretnych przykładów. Na pytanie ucznia, iloma sposobami określana jest Osoba Ducha Świętego, pada odpowiedź nauczyciela, że „bezpośrednio (principaliter) jednym”20. Następnie, na poparcie tego, przytacza Juniliusz dwa fragmenty Pisma Świętego: „Idźcie, chrzcijcie wszystkie narody w imię Ojca i Syna, i Ducha Świętego" (Mt 28,19), oraz „Jesteście bowiem świątynią Ducha Świętego" (1Kor 6,19) Juniliusza? Z całą pewnością autor wskazuje, iż nazwa „Duch Święty” to imię własne, jakim bezpośrednio określany jest On w Piśmie Świętym. Nie można zatem poprzez to imię rozumieć kogoś innego, ponieważ jest to pierwsze i jedyne znaczenie tego słowa. Juniliusz ilustruje to dwoma biblijnymi cytatami. Pierwszy, będący formułą chrzcielną, wyraźnie wskazuje, że oddzielone zostały Osoby Boskie i wymienione po imieniu, w imię też każdej z nich udzielany jest chrzest święty (por. Mt 28,19). W drugim tekście Duch Święty pojawia się znowu w znaczeniu principaliter (bezpośrednio), jako Ten, który jest jedną z Osób Trójcy Świętej (por. 1Kor 6,19) i swoją obecnością uświęca ochrzczonego.

czegoś, stosownie, następnie, z kolei” (por. Plezia, Słownik łacińsko-polski, 48). Zaproponowany przekład consequenter jako „pośrednio” także uzasadnia Juniliusz w swoim tekście. Według niego Bóg w Piśmie Świętym jest consequenter, czyli pośrednio określany, gdy mowa jest o Osobach Bożych, Ich działaniu, lub kiedy stosuje się określenia odnoszące się do Boga, które nie mogą natomiast zostać uznane za przynależące do stworzeń (por. Junilius Africanus, Instituta, I 13).

16 Junilius Africanus, Instituta I, 14 (ŹMT 48,42).

17 Por. Czyżewski, Księgi Pisma Świętego, 152.

18 Junilius Africanus, Instituta I, 14 (ŹMT 48,42-43).

19 Por. Czyżewski, Księgi Pisma Świętego, 131.

20 Junilius Africanus, Instituta I, 17 (ŻMT 48,45).

21 Por. Junilius Africanus, Instituta I, 17 (ŹMT 48,45). 
Na tym jednak Juniliusz nie poprzestaje, gdyż zgodnie z tym, co zapowiedział wcześniej, wyjaśnia, iż jest jeszcze drugi sposób określenia Ducha Świętego w Biblii. W znaczeniu consequenter: „Pośrednio zaś i na podstawie łaski, której On sam udziela, która sama nazywana jest podobnie Duchem Świętym (consequenter vero et ex gratia quam ipse largitur, quae et ipsa similiter spiritus sanctus dicitur)"22. Tak samo jak poprzednio, tak i tutaj posługuje się nasz autor dwoma przykładami biblijnymi: „Duch Święty zstąpi na Ciebie” (Łk 1,35) oraz „Przyjmijcie Ducha Świętego” (J 20,22).

Odnosząc się do powyższych wypowiedzi, H. Kihn jest zdania, iż w tak sformułowanej nauce na temat Ducha Świętego, inspiracją dla Juniliusza był doktryna Teodora z Mopsuestii. Utwierdza go w tym komentarz biskupa z Mopsuestii do słów proroka Joela (3,1: „I wyleję potem Ducha mego na wszelkie ciało”) 23. Teodor wyjaśnia to biblijne zdanie w ten sposób, że Bóg zsyłając swojego Ducha na wszystkich ludzi, chce otoczyć ich swoją opieką. Dodaje też, że Duch Święty w Starym Przymierzu nie był znany jako Osoba, dlatego też wyrażenia „Duch Boży”, „Duch Święty” i inne związane z nimi nazwy oznaczają Jego łaskę, opatrzność i sposób postępowania względem ludzi. Zdaniem Teodora mowa jest o tym w wielu psalmach. Jako przykład podaje Ps 142,10 („Twój dobry duch niech mnie prowadzi po równej ziemi”) oraz Ps 50,13 („Nie odbieraj mi świętego ducha twego”) ${ }^{24}$. H. Kihn wziął pod uwagę jeszcze jeden komentarz biskupa Mopsuestii, mianowicie do proroka Aggeusza (2,5: „duch mój stoi między wami”). Teodor wyjaśnia, że Żydzi i prorocy nic nie wiedzieli o Duchu Świętym jako jednej z Osób Boskich, dlatego też, kiedy Aggeusz mówi: „mój duch stoi między wami”, oznacza to: „będziecie brać udział w mojej łasce, wy którzy stoicie po jej stronie" 25 . Kihn powołuje się dodatkowo na orzeczenia Soboru w Konstantynopolu (553 r.), który potępił niektóre wypowiedzi Teodora, m.in. wyjaśnienie, że Chrystus obiecał Ducha Świętego apostołom (por. J 20,22), jednak nie udzielił Go im faktycznie, tylko tchnął na nich w sposób symboliczny ${ }^{26}$. Dlatego też H. Kihn uważa, że w swoim dziele Juniliusz wyraża podobną myśl jak Teodor z Mopsuestii. Powołując się bowiem na słowa: „przyjmijcie Ducha Świętego” (J 20,22), nie odczytuje ich w tym sensie, że apostołowie rzeczywiście otrzymali Osobę Ducha Świętego, ale tylko Jego łaskę $e^{27}$.

Czy można bez jakichkolwiek wątpliwości przyjąć powyższe opinie H. Kihna, że pneumatologia Juniliusza jest bardzo podobna do pneumatologii Teodora z Mopsuestii, że wpisuje się w nią, przynajmniej w ukazanych przez niego przykładach? Trudno zgodzić się z tego rodzaju poglądami. Należy bowiem zauważyć, że Juniliusz

\footnotetext{
22 Junilius Africanus, Instituta I, 17 (ŹMT 48,45).

23 Według Septuaginty i Wulgaty Jl 2,28.

24 Por. Theodorus Mopsuestenus, Commentarius in XII prophetas minores 2, 28 (PG 66,229).

25 Por. Theodorus Mopsuestenus, Commentarius in XII prophetas minores 2, 5 (PG 66,483).

26 Por. Sobór Konstantynopolitański II, Anatematyzmy przeciwko „Trzem rozdziałom” XII (ŹMT 24,297).

27 Por. Kihn, Theodor von Mopsuestia und Junilius Africanus, 395-397.
} 
najpierw mówi o łasce, której Duch Święty udziela (gratia quam ipse largitur). Wypowiedź ta jest jasna, odnosi się bowiem do łaski, którą daje Duch Święty człowiekowi. Tego rodzaju sposób rozumowania poparty został przez Juniliusza biblijnym fragmentem sceny zwiastowania, podczas którego Gabriel powiedział do Maryi: „Duch Święty zstąpi na Ciebie" (Łk 1,35) ${ }^{28}$. Mimo to Maryja jest Matką w pełnym tego słowa znaczeniu, gdyż Duch Święty nie uczynił z Niej Matki nienaturalnej. On udzielił Jej łask, które proporcjonalne są do ludzkiego macierzyństwa, odnoszącego się do boskiej Osoby Syna Bożego. Można zatem odczytać tutaj pojęcie łaski w znaczeniu daru, którego udziela Duch Święty ${ }^{29}$. Warto odwołać się w tym miejscu do św. Augustyna, który wskazuje, iż imieniem własnym Ducha Świętego jest określenie „Dar”. Duch Święty nie jako Trójca, ale Ten, który jest w Trójcy i nazywa się Go własnym

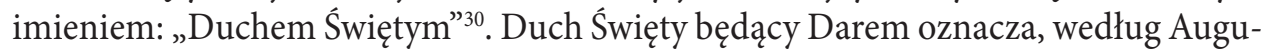
styna, relację, gdyż odnosi się i do Ojca, i do Syna, ponieważ jest On Duchem i Ojca, i Syna. Biskup Hippony zaznacza jednak, że wspomniana relacja nie okazuje się w tym imieniu, ale uwidacznia się wówczas, gdy Duch Święty nazwany jest „Darem Bożym” (Dz 8,20) $)^{31}$ : „Jest bowiem Darem wzajemnym i Ojca, i Syna” ${ }^{\text {32. }}$

W dalszej zaś części swojej wypowiedzi Juniliusz wymienia łaskę, która nazywana jest Duchem Świętym (quae et ipsa similiter spiritus sanctus dicitur) ${ }^{33}$. Wskazuje na to, według autora Instituta, zdanie skierowane przez Jezusa do apostołów: „Przyjmijcie Ducha Świętego” (J 20,22). Wypowiedziane w taki sposób nie oznacza otrzymania przez apostołów wyłącznie łaski Ducha Świętego, ale Osoby Ducha Świętego. Autor Instituta wyraźnie bowiem stwierdza, że „łaska nazywana jest podobnie Duchem Świętym" ${ }^{\prime 4}$. Dla Juniliusza słowo gratia i Spiritus Sanctus jest więc tożsame, ponieważ w jednym i drugim przypadku chodzi o dar osobowy, którym zgodnie z obietnicą Chrystusa, jest dla apostołów Duch Święty. Można pójść jeszcze dalej, mianowicie, iż jest On darem Ojca dla całego Kościoła ${ }^{35}$. W podobny sposób wypowiada się św. Cyryl Aleksandryjski, kiedy pisze: „posiadamy nie tylko łaskę [Ducha], lecz samego Ducha, który w nas mieszka" ${ }^{36}$. Zdanie to można rozumieć w takiej samej perspektywie jak widzi je Juniliusz. Duch Święty to osobowy dar dany człowiekowi w postaci łaski. Wybrał On człowieka, by w nim zamieszkać.

Wypowiedzi Juniliusza inspirują do jeszcze innych wniosków. Skoro mówi on, że Duch Święty określany jest w Biblii na podstawie łaski, której sam udziela, co wię-

\footnotetext{
28 Por. Junilius Africanus, Instituta I, 17 (ŹMT 48,45).

29 Por. Czyżewski, Księgi Pisma Świętego, 180.

30 Augustinus, De Trinitate V, XII, 13 (Stokowska, 209).

31 Por. Augustinus, De Trinitate V, XI, 12 (Stokowska, 208-209). Zob. także Eborowicz, Rzut oka na pneumatologięśw. Augustyna, 199.

32 Augustinus, De Trinitate V, XI, 12 (Stokowska, 209).

33 Por. Junilius Africanus, Instituta I, 17 (ŹMT 48,45).

34 Por. Junilius Africanus, Instituta I, 17 (ŹMT 48,45).

35 Por. Czyżewski, Księgi Pisma Świętego, 180.

Cyrillus Alexandrinus, Commentarii in Iohannem, V, VII, 39 (PG 73,757).
} 
cej, ona też nazywana jest Duchem Świętym, to wydaje się zasadne wskazać na dwa pojęcia obecne w późniejszej teologii. Chodzi o rozróżnienie między gratia creata i gratia increata. Pierwsze z nich odpowiadałoby łasce rozumianej jako dary Ducha Swiętego. Od Niego bowiem one pochodzą i z Nim są związane. Drugie natomiast pojęcie byłoby właściwe dla Ducha Świętego określanego jako $\mathrm{Dar}^{37}$.

Juniliusz zwraca uwagę na jeszcze jeden istotny szczegół, mianowicie na proroctwa, jakie spełniły się w życiu Chrystusa, a odnosiły się do Ducha Świętego. Nasz autor mówi o tym, że Pismo Święte wskazuje na „wlanie Ducha Świętego, na które człowiek przez niego przyjęty zasłużył (sancti spiritus infusionem, quam utique homo ab eo susceptus emeruit)"38. Juniliusz wyjaśnia to na podstawie kilku przykładów z życia Jezusa, w których dokonało się owo infusio: w czasie zwiastowania, podczas wzrastania Jezusa w latach i mądrości, w czasie chrztu w Jordanie, kiedy dokonywał cudownych dzieł, gdy nauczał i gdy zmartwychwsta1 ${ }^{39}$.

\section{Trynitarny charakter pneumatologii Juniliusza}

Juniliusz wyjaśnia także pneumatolgię w powiązaniu z tajemnicą Trójcy Świętej. Na pierwszy rzut oka można powiedzieć, iż nie jest to niczym nadzwyczajnym, tym bardziej że wielu autorów piszących o Duchu Świętym przed Juniliuszem w taki sposób ustawiało doktrynę na temat trzeciej Osoby Boskiej. Mimo wszystko zauważyć można w myśli naszego autora ciekawy sposób, w jaki dochodzi on do pokazania Bóstwa Ducha Świętego, Jego równości z Ojcem i Synem oraz odrębności od Ojca i Syna. Nie zapominajmy też, że nie mamy do czynienia z traktatem de Spiritu Sancto, ale jedynie z krótkim dziełem uważanym za wprowadzenie do ogólnego poznania Pisma Świętego.

Juniliusz jest bardzo syntetyczny w swoim wykładzie. Ostatnie rozdziały pierwszej części jego isagogi (por. I, 14-20) poświęcone zostały Trójcy Świętej. Wspomnieliśmy już wcześniej, że przy tej okazji pada najpierw znane już pytanie ucznia o ilość sposobów określania przez Pismo Święte Osób bądź też hipostaz Boskich. Nauczyciel na to odpowiada, że Trójca Święta została w Piśmie Świętym określona bezpośrednio (principaliter) i pośrednio (consequenter $)^{40}$. Zatrzymamy się najpierw nad tym, że poszczególne Osoby Boskie, w tym także Duch Święty, określane są w Piśmie Świętym pośrednio (consequenter). Juniliusz wyjaśnia to zagadnienie w następujący sposób:

\footnotetext{
Por. Czyżewski, Księgi Pisma Świętego, 181.

Junilius Africanus, Instituta II, 22 (ŻMT 48,75).

Por. Junilius Africanus, Instituta II, 22 (ŹMT 48,75).

Por. Junilius Africanus, Instituta I, 14 (ŹMT 48,42).
} 
Kiedy mówię Bóg (Deus), mówię to, co odnosi się do istoty (ad essentiam), a kiedy mówię Wszechmocny (omnipotens), mówię, co odnosi się do działania (ad operationem), a kiedy mówię Niezmienny (inmutabilis), mówię to na podstawie analogii do stworzeń (ex collatione ad creaturas), chociaż co innego pierwsze słyszenie oznacza, to jednak pośrednio (consequenter) rozumiem jako Boga Ojca i Syna, i Ducha Świętego albo razem, albo oddzielnie ${ }^{41}$.

Po tym stwierdzeniu, Juniliusz nie posługuje się żadnymi biblijnymi przykładami, prawdopodobnie dlatego, by nie powielać argumentów, na które wskazał we wcześniejszych swoich wypowiedziach, kiedy mówił o Ojcu i Synu ${ }^{42}$. Nie ma wątpliwości, że kiedy używa sformułowania „Boża istota” (divina essentia), ma na myśli bóstwo, które posiada Duch Święty, a zatem jest prawdziwym Bogiem. Świadczą o tym słowa Juniliusza, kiedy odpowiada na pytanie ucznia, jakimi sposobami pośrednio określany jest Bóg. Wówczas nasz autor stwierdza, że kiedy Pismo Święte „wymienia Ojca, to chociaż pierwsze wrażenie wskazuje na rodzica, pośrednio jednak rozumiemy Boga, podobnie i wtedy, gdy wymienia Syna lub Ducha Świętego" ${ }^{43}$. Również drugi przymiot, mianowicie „Wszechmogący” (omnipotens), Biblia nie tylko odnosi do Ojca, ale także do Syna i do Ducha Świętego: „mimo że słowo to oznajmia najpierw Jego działanie, pośrednio jednak rozumiemy Boga"44. Wreszcie Juniliusz dostrzega również dowód na bóstwo Ducha Świętego w tym, co nazwał „analogią do stworzeń” (collatio ad creaturas). Chodzi mianowicie o przymioty, które są właściwe dla Ducha Świętego, w żaden jednak sposób nie mogą być przypisane człowiekowi. Kluczowe jest dla niego słowo „Niewidzialny” odniesione do Boga: „gdy [Pismo] określa jako Niewidzialnego (invisibilem), to chociaż bezpośrednio opiewa tego, którego śmiertelni nie mogą oglądać, a przez analogię z nami przypisuje naszemu Stwórcy to, czym my nie jesteśmy, pośrednio jednak rozumiemy, że oznacza Boga" ${ }^{2}$.

Juniliusz proponuje zatem, by wymienione terminy: „Bóstwo”, „Wszechmocny”, „Niewidzialny”, wcześniej zaś wspomina „Niezmienny”, odczytać w kluczu trynitarnym, co sugeruje, jego zdaniem, Pismo Święte. W taki bowiem sposób określona została Trójca Święta, wszystkie zaś te pojęcia przynależą Osobom Boskim, które tworzą jedność (simul), albo też mogą one określać każdą z Nich osobno (singulos $)^{46}$.

$\mathrm{Na}$ tym jednak pneumatologia Juniliusza nie wyczerpuje się. Odpowiedź na pytanie o ilość sposobów, jakimi określana bywa Osoba Ducha Świętego, ma swój dalszy ciąg. Nauczyciel stwierdza, że

\footnotetext{
41 Junilius Africanus, Instituta I, 14 (ŹMT 48,42-43).

42 Por. Junilius Africanus, Instituta I, 13 (ŹMT 48,41-42).

43 Junilius Africanus, Instituta I, 13 (ŹMT 48,42).

44 Junilius Africanus, Instituta I, 13 (ŹMT 48,42).

45 Junilius Africanus, Instituta I, 13 (ŹMT 48,42).

46 Por. Junilius Africanus, Instituta I, 14 (ŹMT 48,43)
} 
także Osoba (persona) Ojca i Syna pośrednio (consequenter) wskazuje na Ducha Świętego, ponieważ cokolwiek byśmy powiedzieli dotyczącego ich, pośrednio rozumiemy Osobę (personam) Ducha Świętego albo jako współdziałającą (cooperatricem), albo jako równą pod względem istoty (consubstantialem) ${ }^{47}$.

Należy zwrócić uwagę na kilka ważnych wątków nauki naszego autora o Duchu Świętym, jakie zawarł w powyższej wypowiedzi. Pierwszy jest taki, że dwukrotnie w zacytowanym tekście używa terminu persona w odniesieniu do Ducha Świętego, podkreślając w ten sposób, iż jest On tak samo Osobą jak Ojciec i Syn. Poza tym, mowa jest o „współdziałaniu” (cooperatio) Osoby Ducha Świętego z Ojcem i Synem. Nic nie jest obce Duchowi Świętemu, co czyni Ojciec i Syn. Zaznacza Juniliusz tym samym jedność działania, co jest wyrazem jedności, jaką tworzy Trójca Święta. W zacytowanej wypowiedzi nasz autor zwraca uwagę na jeszcze jeden istotny element, mianowicie używa terminu consubstantialis, przez co podkreśla równość Ducha Świętego z Ojcem i Synem. Jeżeli mówiliśmy wcześniej o wyraźnym wpływie św. Augustyna na Juniliusza, w tym miejscu należałoby także to odnotować. Biskup Hippony w De fide et symbolo posługuje się bowiem tym samym słowem consubstantialis, w celu wykazania, że Duch Święty ani nie jest mniejszy od Ojca, ani od Syna, ale współistotny Ojcu i Synowi ${ }^{48}$.

Należy wskazać na jeszcze jeden element pneumatologii Juniliusza, którą wpisuje w ramy doktryny trynitarnej. Na pytanie ucznia: „Co mają wspólnego Osoby Trójcy?"49, nauczyciel odpowiada:

Ojciec nigdy nie jest nazywany Synem, ani przy połączeniu słów nie jest Duchem Świętym, chociaż oddzielnie może być nazwany i Duchem, i Świętym. Ani Syn nie może być nazwany Ojcem, albo przy łącznym określeniu Duchem Świętym. Ponadto imienia Ojca ani Syna nie przypisuje się Duchowi Świętemu ${ }^{50}$.

Juniliusz, na podstawie imion Boskich, wyraźnie różnicuje trzy Osoby Boskie. Podobną wypowiedź spotykamy u św. Augustyna, który w cytowanym już De fide et symbolo pisze, iż Ducha Świętego „nie nazywamy ani Ojcem, ani Synem, lecz tylko Duchem Świętym" ${ }^{1}$. Natomiast w De Trinitate, na podstawie świadectw Pisma Świętego, biskup Hippony wykazuje, że Duch Święty jest Duchem Ojca i jest Duchem Syna, czyli Duchem Obu ${ }^{52}$. Wskazuje tym samym na jedność Osób Boskich. Juni-

\footnotetext{
47 Junilius Africanus, Instituta I, 17 (ŹMT 48,45).

48 Por. Augustinus, De fide et symbolo IX, 16 (ŹMT 53,43)

49 Junilius Africanus, Instituta I, 18 (ŹMT 48,45).

50 Junilius Africanus, Instituta I, 18 (ŹMT 48,45).

51 Augustinus, De fide et symbolo IX, 19 (ŹMT 53,49).

52 Por. Augustinus, De Trinitate V, XI, 12 (Stokowska, 208-209). Zob. także Augustinus, Sermo 214,10: „Jeden Bóg Ojciec, jeden Bóg Syn, jeden Bóg Duch Święty. Ojciec i Syn, i Duch Ŝwięty to jednak nie trzej
} 
liusz dowodzi podobnie jak Augustyn, kiedy mówi, że Duch Święty „to Duch Ojca i Syna"53.

Wykazane w tym miejscu podobieństwo Juniliusza z Augustynem jest o tyle ważne, że zostaje podważona teoria znanego nam już niemieckiego teologa H. Kihna, który dostrzega wpływ na naszego autora przede wszystkim Teodora z Mopsuestii. Otóż wspomniany uczony jest zdania, że Teodor z Mopsuestii w komentarzu do Mt 1,18 wysuwa podobną tezę jak Juniliusz, a mianowicie uważa, że imion Ojciec lub Syn nie przypisuje się Duchowi Świętemu ${ }^{54}$. Świadczy to, według Kihna, o wpływie biskupa Mopsuestii na Juniliusza ${ }^{55}$. Nie bierze on też pod uwagę żadnego innego oddziaływania na naszego autora. Powiedzieliśmy wyżej, że w takim samym duchu wypowiada się św. Augustyn.

Biorąc pod uwagę wszystkie te wypowiedzi nie wolno zapominać, że Juniliusz, mówiąc o Duchu Świętym, który jest Duchem Ojca i Syna, wpisuje się wyraźnie w tradycję tego określenia, jakie pojawia się w Nowym Testamencie (por. Ga 4,6; Mt 10,20). Dlatego odwoływał się do niego nie tylko Teodor z Mopsuestii, ale także wielu innych pisarzy wczesnochrześcijańskich, aby wskazać na jedność Osób Boskich ${ }^{56}$.

\section{Podsumowanie}

Podsumowując powyższe rozważania, należy najpierw spojrzeć z uznaniem na isagogę Juniliusza Afrykańczyka, w której zawarł on najważniejsze tematy teologiczne, w tym również kwestie odnoszące się do Ducha Świętego. W pneumatologii naszego autora odnajdujemy dwa istotne zagadnienia. Pierwsze związane jest $\mathrm{z}$ ukazaniem Ducha Świętego w perspektywie łaski. Juniliusz przedstawia tę kwestię w podwójnym niejako aspekcie: daru, jaki otrzymują wierzący w Chrystusa, i daru (łaska), jakim jest On sam dla Kościoła.

Drugie zagadnienie ukazane przez Afrykańczyka w związku z jego pneumatologią odnosi się do kwestii trynitarnej. Juniliusz posłużył się technicznymi zwrotami: principaliter, consequenter, przy pomocy których wykazał, na podstawie Pisma Świętego, że Duch Święty jest Osobą, prawdziwym Bogiem, kimś innym niż Ojciec i Syn, z drugiej zaś strony stanowi z Nimi jedno pod względem natury. Duch Święty bez

bogowie, lecz jeden Bóg. Tak aby Ojciec sam nie był tym, czym Syn, ani Syn nie był tym, czym Ojciec, ani Duch Święty nie był bądź Ojcem, bądź to Synem, lecz Ojciec jest Ojcem Syna, a Syn Synem Ojca, a Duch Święty Duchem Ojca i Syna (Spiritus Sanctus Patris et Filii Spiritus). A każdy z osobna jest Bogiem i cała Trójca jednym Bogiem" (PL 38,1071). 
wahania nazywany jest przez Juniliusza Bogiem, Wszechmocnym, Niezmiennym, Niewidzialnym, współpracuje z Ojcem i Synem. Wszystkie wymienione przymioty nie odnoszą się wyłącznie do jednej Osoby Boskiej, one przynależą do każdej z nich.

$\mathrm{Na}$ koniec należy jeszcze wskazać na ewentualne wpływy, jakie są widoczne w myśli pneumatologicznej Juniliusza. Podstawowym źródłem jest przede wszystkim św. Augustyn, nie zaś Teodor z Mopsuestii. Porównanie bowiem wypowiedzi biskupa Hippony z wypowiedziami Afrykańczyka na tematy związane z Duchem Świętym, przekonują o wyraźnym odciśnięciu jego piętna na naszym autorze.

\section{Bibliografia}

\section{Źródła}

Augustinus, De fide et symbolo (PL 40, 181-196); tłum. L. Gładyszewski: Augustyn, Piotr Chryzolog, Wenancjusz Fortunatus, Symbol Apostolski w nauczaniu Ojców (Źródła Myśli Teologicznej 53; Kraków: Wydawnictwo WAM 2010) 16-57.

Augustinus, De Trinitate libri quindecim (PL 42,819-1098); tłum. M. Stokowska: Św. Augustyn, O Trójcy Świętej (Kraków: Znak 1996).

Augustinus, Sermones (PL 38-39).

Cassiodorus, Institutiones (PL 70,1105-1150).

Cyrillus Alexandrinus, Commentarii in Iohannem (PG 73,9-1056).

Junilius Africanus, Instituta regularia divinae legis, Theodor von Mopsuestia und Junilius Africanus als Exegeten (red. H. Kihn) (Freiburg im Breisgau: Herder 1880) 465-528; PL 68,15-42; tłum. B. Czyżewski: Juniliusz Afrykańczyk, Zasady Prawa Bożego (Źródła Myśli Teologicznej 48; Kraków: Wydawnictwo WAM 2008).

Mansi, J.D. (red.), Sacrorum Conciliorum Nova et Amplissima Collectio (Florentinae 1759; reprint: Paris 1901); tłum. T. Wnętrzak: „Sobór Konstantynopolitański II (553)”, Dokumenty Soborów Powszechnych (red. A. Baron - H. Pietras) (Źródła Myśli Teologicznej 24; Kraków: Wydawnictwo WAM 2001) I, 259-303.

Theodorus Mopsuestenus, Commentarius in XII prophetas minores (red. H.N. Sprenger) (Einleitung und Ausgabe, Göttinger Orientforschungen. V. Reihe: Biblica et Patristica 1; Wiesbaden: Harrassowitz 1977).

Theodorus Mopsuestenus, Fragmenta in Matthaeum (PG 66,703-714).

\section{Opracowania}

Buchwald, W. - Hohlweg, A. - Prinz, O., „Junilius Africanus”, Dictionnaire des auteurs grecs et latins de l'antiquité et du moyen âge (tł. i red. J.-D. Berger - D. de Decker) (Turnhout: Brepols 1991) 496.

Bruns, P., „Junilius Africanus”, Lexicon der antiken christlichen Literatur (Freiburg - Basel Wien: Herder 1999) II, 365.

Częsz, B., Duch Święty został nam dany. Nauczanie Ojców i wiara starożytnego Kościoła (Gniezno: Gaudentinum 1998). 
Czyżewski, B., „Elementy angelologii w Instituta regularia divinae legis Juniliusza Afrykańczyka”, w: Minister Verbi. Liber sollemnis excellentissimo domino domino archiepiscopo Henrico Muszyński metropolitae gnesnensi ad honorandum decimum quartum eiusdem vitae lustrum expletum dedicatus oblatusque (red. P. Podeszwa - W. Szczerbiński) (Gniezno: Prymasowskie Wyższe Seminarium Duchowne 2003) 409-420.

Czyżewski, B., „Isagoga Juniliusza Afrykańczyka: pomoc czy przeszkoda w poznawaniu Biblii?", Spiritus Sanctus et Ecclesia. Opuscula Bogdano Częsz septuagenario dedicata (Poznań: UAM 2015) 11-19.

Czyżewski, B., „Wprowadzenie”, Juniliusz Afrykańczyk, Zasady prawa Bożego (Źródła Myśli Teologicznej 48; Kraków: Wydawnictwo WAM 2008) 7-20.

Czyżewski, B., „Wykorzystanie teorii egzegezy biblijnej w duszpasterstwie okresu patrystycznego w świetle wybranych źródeł", Problemy duszpasterskie starożytnego Kościoła (red. J. Pałucki et al.) (Lublin: Polihymnia 2009) 147-159.

Czyżewski, B., Księgi Pisma Świętego w ujęciu isagogi Juniliusza Afrykańczyka (Poznań: Wydawnictwo Naukowe UAM 2003).

Eborowicz, W., „Rzut oka na pneumatologię św. Augustyna”, VoxPatrum 8/14 (1988) 197-206.

Gessel, W.M., „Junilius (Junillus) Africanus”, Lexikon für Theologie und Kirche (red. J. Höfer K. Rahner) (Freiburg - Rom - Wien 1996) V, 1101.

Guillaumont, A., „Justinien et l'Église de Perse”, Dumbarton Oaks Papers 23-24 (1969-1970) 39-6641-67.

Kihn, H., Theodor von Mopsuestia und Junilius Africanus als Exegeten (Freiburg im Breisgau: Herder 1880).

Kopaliński, W., Słownik wyrazów obcych i zwrotów obcojęzycznych, wyd. 14 (Warszawa: Wiedza Powszechna 1983).

Mannino, B.M., „Gli Instituta di Giunilio: alcuni aspetti esegetici”, Annali di storia dell'esegesi 8/2 (1991) 405-419.

Peterson, M.O.-E., „Giunilio Africano”, Enciclopedia Cattolica (Roma: Ente per l'Enciclopedia Cattolica e per il Libro Cattolico 1951) VI, 762-763.

Pirot, L., Loeuvre exégétique de Théodore de Mopsueste (Rome: Pontificii Instituti Biblici 1913).

Szymczak, M. (red.) Słownik języka polskiego. I. A-K (Warszawa: Wydawnictwo Naukowe PWN 1994).

Plezia, M. (red.), Słownik łacińsko-polski. I. A-C (Warszawa: Państwowe Wydawnictwo Naukowe 1959).

Plezia, M. (red.), Słownik łacińsko-polski. IV. P-R (Warszawa: Państwowe Wydawnictwo Naukowe 1974).

Stein, E., „Deux questeurs de Justinien et l'emploi des langues dans ses novelles”, Bulletin de la Classe des Lettres et des Sciences Morales et Politiques 23 (1937) 365-390. 